\title{
Analisis Peran UU No 6 Tahun 2014 di Dalam Mewujudkan Administrasi Desa yang Efektif dan Efisien
}

\author{
David Firna Setiawan, Ibnu Fatkhu Royana, Toebagus Galang Windi Pratama, Aryan Eka Prastya Nugraha
}

Universitas PGRI Semarang

\begin{abstract}
Pasal 86 UU Desa Menyebutkan bahwa Hak dan kewajiban Desa yaitu, (1) desa berhak mendapatkan akses informasi melalui sistem informasi Desa yang dikembangkan oleh Pemerintah Daerah Kabupaten/Kota serta (2) Pemerintah dan Pemerintah Daerah wajib mengembangkan sistem informasi Desa dan pembangunan Kawasan Perdesaan yang menunjukkan bahwa desa wajib menguasai komputer namun hal ini menimbulkan kekhawatiran akan ketidakefektifan dari sumber daya manusia dari perangkat desa yang belum melek komputer sehingga perlu dicari solusinya melalui penelitian yang bersifat yuridis normatif. Hasil penelitian menunjukkan bahwa walaupun maksud dan tujuan dari pasal 86 ini baik yakni penngkatan sistem informasi desa, namun dalam prakteknya masih banyak penduduk indonesia yang belum melek komputer ditambah dengan tingkat minat baca yang rendah sehingga bila hal ini teus berlanjut akan menjadi tidak efektif untuk itu solusi yang bisa diberikan ialah (1) regenerasi perangkat desa dan (2) pengembangan sumber daya manusia.
\end{abstract}

Kata Kunci - UU No.6 Tahun 2014, Adminsitrasi Desa, Efektif dan Efisien.

Abstract

Article 86 of the Village Law in Indonesia Suggests that the Village's Rights and obligations are (1) the village is entitled to access information through the Village information system developed by the Regency / City Government and (2) the Government and the Regional Government shall develop the Village information system and the Rural Area development indicates that the village is required to master the computer but this raises concerns about the ineffectiveness of human resources from village devices that have not computer literate so it needs to find a solution through research that is juridical normative. The results indicate that although the intent and purpose of article 86 is good, that is the improvement of the village information system, but in practice there are still many Indonesians who are not yet computer literate coupled with a low level of reading interest so that if this continues it will be ineffective for that solution which can be given are (1) regeneration of village apparatus and (2) human resource development.

Keywords - Law No.6 Year 2014, Village Administration, Effective and Efficient

\section{Pendahuluan}

Dalam era dimana perkembangan IPTEK terjadi dengan amat pesat, perangkat negara terlebih yang berada dekat dengan masyarakat sepertiperangkatdesa dituntut pemerintah sebagaimana dapat dilihat pada Pasal 86 UU Undang-Undang Nomor 6 Tahun 2014 tentang desa yang mengamanatkan kepada pemerintah dan pemerintah daerah untuk mengembangkan sistem informasi desa dan pembangunan kawasan perdesaan, meliputi fasilitas perangkat keras dan perangkat lunak, jaringan, serta sumber daya manusia. Oleh sebab itu, pemahaman mengenai pengoperasian serta pemahaman mengenai kerusakan komputer dan cara memperbaikinya menjadi salah satu keterampilan yang dibutuhkan oleh perangkat desa.

Berdasarkan hal tersebut maka ada 2 hal terkait dengan hak dan kewajiban desa mengenai pengembangan sistem informasi yang perlu diperhatikan. Hak dan kewajiban tersebut yaitu, (1) desa berhak mendapatkan akses informasi melalui sistem informasi Desa yang dikembangkan oleh Pemerintah Daerah Kabupaten/Kota serta (2) Pemerintah dan Pemerintah Daerah wajib mengembangkan sistem informasi Desa dan pembangunan Kawasan Perdesaan. Hal ini tentu bukan menjadi masalah bagi perangkat desa yang sudah melek komputer, namun yang menjadi permasalahan disini adalah sumber daya manusia dari perangkat desa yang belum memahami komputer karena bagi generasi muda yang lahir di era 1990 ke atas, teknologi komputer tentu bukanlah sebuah ancaman karena mereka sudah terbiasa dengan teknologi ini, namun bagi mereka yang berkembang sebelum era milenial, penggunaan teknologi adalah hal yang menakutkan. Ketakutan tersebut diakibatkan adanya keharusan untuk mempelajari berbagai hal agar mereka dapat berinteraksi dengan komputer, hal yang bagi para generasi ini belum begitu dikenal dibandingkan dengan generasi muda yang sudah akrab dengan teknologi ini dari kecil.

A. Pokok Permasalahan

Berdasarkan hal tersebut maka tim penulis merasa tertarik untuk mengkaji apakah dengan adanya Pasal 86 UU Undang-Undang Nomor 6 Tahun 2014 tentang desa ini benar benar berperan di dalam mewujudkan administrasi desa yang efektif dan efisien yang dirumuskan dalam pokok permasalahan sebagaimana bisa dilihat di bawah: 
- Apa Peran Pasal 86 UU Undang-Undang Nomor 6 Tahun 2014 Tentang Desa Dalam Mewujudkan Administrasi Desa Yang Efektif Dan Efisien ?

- Kendala Apa Yang Menghambat Pelaksanaan Ketentuan Pasal 86 UU Undang-Undang Nomor 6 Tahun 2014 Tentang Desa Dalam Mewujudkan Administrasi Desa Yang Efektif Dan Efisien?

- Bagaimana Pemecahan Dari Kendala Yang Menghambat Pelaksanaan Ketentuan Pasal 86 UU Undang-Undang Nomor 6 Tahun 2014 Tentang Desa Dalam Mewujudkan Administrasi Desa Yang Efektif Dan Efisien

\section{Metode PenElitian}

Metode Penelitian yang digunakan adalah Penelitian ini merupakan penelitian hukum yang menggunakan pendekatan yuridis normatif (normative legal research). (Rony;1990) Menurut Soerjono Soekanto penelitian yuridis normatif merupakan penelitian terhadap asas-asas hukum. Dalam penelitian ini pendekatan normatif dilakukan untuk membedah produk hukum indonesia yakni Pasal $86 \mathrm{UU}$ Undang-Undang Nomor 6 Tahun 2014 Tentang Desa Dalam Mewujudkan Administrasi Desa Yang Efektif Dan Efisien dengan data primer yang berasar dari pemikiran tim penulis dan undang undang terkait dan data sekunder dari literatur dan data data yang relevan.

\section{HASIL PENELITIAN DAN PEMBAHASAN}

\section{A. Peran Pasal 86 UU Undang-Undang Nomor 6 Tahun} 2014 Tentang Desa Dalam Mewujudkan Administrasi Desa Yang Efektif Dan Efisien

Perangkat Desa adalah salah satu organ pemerintah desa, selain Kepala Desa. Definisi dari perangkat desa sebagaimana dapat dilihat pada Pasal 1 angka 3 UU Desa, kedudukan Perangkat Desa adalah 'pembantu' bagi Kepala Desa dalam menjalankan fungsi pemerintahan. Dalam sistem ketatanegaraan Indonesia.

Perangkat Desa diatur dalam Pasal 48-53 UU Desa. Secara ringkas, pasal-pasal ini mengatur tentang kedudukan dan tugas Perangkat Desa; pengangkatan dan pemberhentian; penghasilan; serta larangan-larangan dalam menjalankan tugas. Aspek-aspek tersebut disajikan dalam penuturan pasal-pasal, rincian rumusan dan penjelasannya sebagaimana dapat dilihat pada pasal 49 UU desa sebagai berikut :

- Perangkat Desa sebagaimana dimaksud dalam Pasal 48 bertugas membantu Kepala Desa dalam melaksanakan tugas dan wewenangnya;

- Perangkat Desa sebagaimana dimaksud pada ayat (1) diangkat oleh Kepala Desa setelah dikonsultasikan dengan camat atas nama Bupati/Walikota;

- Dalam melaksanakan tugas dan wewenangnya, Perangkat Desa sebagaimana dimaksud pada ayat (1) bertanggung jawab kepada Kepala Desa.

Sesuai dengan amanat undang undang desa, perangkat desa yang berada pada posisi yang amat dekat dengan masyarakat dituntutu untuk dapat terus berkembang untuk dapat menjawab kebutuhan masyarakat maka dari itu sebagaimana amanat dari pasal 86 UU Desa yaitu :

- Desa berhak mendapatkan akses informasi melalui sistem informasi Desa yang dikembangkan oleh Pemerintah Daerah Kabupaten/Kota.

- Pemerintah dan Pemerintah Daerah wajib mengembangkan sistem informasi Desa dan pembangunan Kawasan Perdesaan.

- Sistem informasi Desa sebagaimana dimaksud pada ayat (2) meliputi fasilitas perangkat keras dan perangkat lunak, jaringan, serta sumber daya manusia.

- Sistem informasi Desa sebagaimana dimaksud pada ayat (2) meliputi data Desa, data Pembangunan Desa, Kawasan Perdesaan, serta informasi lain yang berkaitan dengan Pembangunan Desa dan pembangunan Kawasan Perdesaan.

- Sistem informasi Desa sebagaimana dimaksud pada ayat (2) dikelola oleh Pemerintah Desa dan dapat diakses oleh masyarakat Desa dan semua pemangku kepentingan.

- Pemerintah Daerah Kabupaten / Kota menyediakan informasi perencanaan pembangunan Kabupaten / Kota untuk Desa.

Sistem informasi sebagaimana yang dimaksud diatas didukung dengan alokasi yang tinggi dari pemerintah untuk pembangunan desa sebesar 60 Triliun (Dhita;2018).

Ketentuan penggunaan dana untuk pembangunan desa sebagaimana tercantum dalam Peraturan Kepala Lembaga.

Kebijakan Pengadaan Barang/Jasa Pemerintah (Perka LKPP) No, 13 Tahun 2013 dan Perka No. 22 Tahun 2015. Di sana sudah dijelaskan mengenai pengadaan barang/jasa di tingkat desa. Tata cara atau pedoman pengadaan barang/jasa di desa yang pembiayaannya berasal dari APBDes diatur oleh Walikota atau Bupati dalam bentuk Peraturan Walikota/Bupati.

Langkah awal dari proses pengadaan barang dan jasa adalah pembentukan Tim Pengelola Kegiatan (TPK). TPKlah yang kemudian akan bertanggungjawab dengan Proyek Pengadaan Barang/Jasa. TPK ditetapkan oleh Kepala Desa yang pembentukannya melalui persetujuan pemerintah desa dan berbagai unsur masyarakat. Penetapannya dengan Surat Keputusan yang ditandatangani Kepala Desa. Setelah itu TPK bakal bertangungjawab mulai dari persiapan, pelaksanaan, pengawasan, penyerahan, pelaporan dan pertanggungjawaban hasil pekerjaan.

Pada pelaksanannya, segala yang dibutuhkan dalam proyek itu harus mengutamakan kemampuan dan kebutuhan desa. Misalnya desa tersebut memiliki keunggulan di bidang tertentu maka pengadaan barang dan jasa desa lebih menitikberatkan pada bidang tesebut. Pun sama halnya dengan kebutuhan desa dimana disini kebutuhan yang vital adalah komputer, karena dengan adanya perangkat ini selain mempermudah dan mempercepat pelayanan terhadap masyarakat juga dapat menekan biaya yang dibebankan 
pada pemerintah desa seperti penggunaan kertas, dan tenaga perangkat desa.

\section{B. Hambatan-Hambatan yang Timbul}

Tak dapat dipungkiri bahwa semua kemudahan kemudahan itu amat sangat memudahkan perangkat desa di dalam memberikan pelayanan kepada masyarakat namun Salah satu hambatan yang muncul adalah kualitas sumber daya manusia (brainware) yang tidak lagi mumpuni. Keadaan ini memunculkan persepsi bahwa undang-undang desa merupakan sebuah jeratan agar mereka mulai belajar menggunakan komputer dan berinteraksi dengan teknologi.

Sebagai gambaran tim penulis akan menyajikan datadata relevan untuk menggambarkan hambatan hambatan yang timbul terhadap pelaksanaan pasal 86 Undang undang Desa sebagaimana dapat dilihat di bawah.

TABEL 1. JUMLAH PEGAWAI NEGERI SIPIL DI INDONESIA

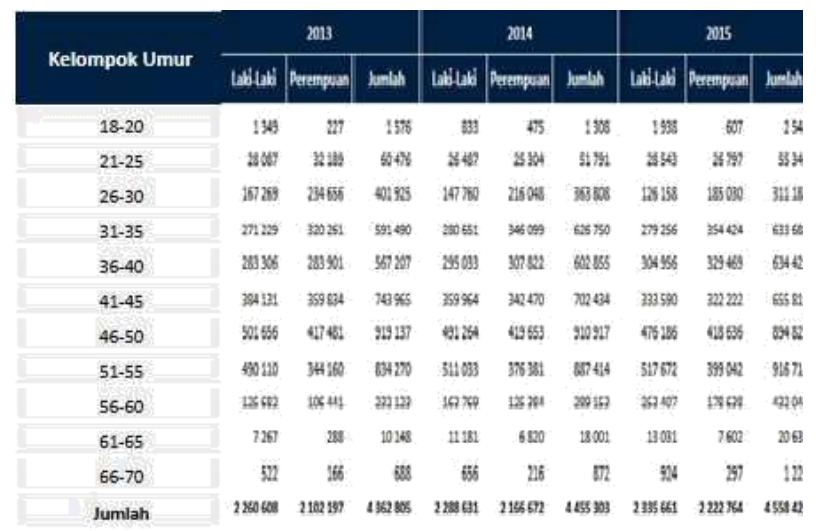

Berdasarkan Usia 2013-2016.

Tabel diatas menunjukkan bahwa jumlah pegawai negeri sipil yang berusia 40 tahun keatas banyak, beberapa kali dari jumlah pegawai negeri sipil yang berusia 40 tahun ke bawah. Hal ini mungkin tidak menjadi masalah bila memang pegawai negeri sipil yang berusia diatas 40 tahun tersebut memang kompeten namun perlu diingat bahwa mereka lahir di era dimana komputer belum berkembang sepesat generasi muda saat ini sehingga dikhawatirkan generasi ini akan mengalami kesulitan untuk mengejar ketertinggalan.

Argumen dari tim penulis bukan tidak berdasar, karena berdasarkan data penelitian yang dilakukan Central Connecticut State University terkait minat baca menempatkan Indonesia di posisi ke-60 dari 61 negara, setingkat di atas Botswana. Kondisi ini sangat ironis karena berdasarkan data yang didapat dari Asosiasi Penyelenggara Jaringan Internet Indonesia (APJII) pada 2016, ada 63,1 juta orang yang mengakses internet dari smartphone. namun hanya 2,2 juta orang saja yang mengakses dari komputer bila dibandingkan dengan tingkat minat membaca, dikhawatirkan dengan adanya akses internet yang melimpah tersebut malah akan membuat masyarakat tidak dapat membedakan mana informasi yang benar dan salah (Hoax).

\section{Solusi Terhadap Hambatan Yang Timbul}

Sebagaimana yang diutarakan Friedman (1994), bahwa ada 3 unsur dari sistem hukum yakni substansi, struktur dan kultur hukum. apabila substansi adalah segala aturan aturan hukum yang tertulis maupun yang tidak tertulis (cita hukum) dan kultur adalah masyarakat yang merupakan subjek hukumnya maka lembaga lembaga hukum adalah struktur atau pondasi dari hukum itu sendiri, ia berperan penting sebagai kerangka yang menahan pondasi hukum indonesia yang berusaha mewujudkan tujuan bangsa Indonesia yakni keadilan sosial bagi seluruh rakyat indonesia untuk itu "struktur Hukum" ini perlu mendapatkan perhatian khusus dimana setelah melihat data data yang ada maka solusi yang bisa diberikan ada dua yakni, (1) regenerasi perangkat desa dan (2) pengembangan sumber daya manusia.

Regenerasi Perangkat desa, sebagai sokusi pertama dinilai oleh tim penulis sangat relevan di dalam meningkatkan kinerja pelayanan perangkat desa karena bagi mereka yang hidup dan berkembang di era milenial di mana komputer dan teknologi telah sering digunakan, maka penggunaan komputer merupakan kemampuan yang biasa dan mudah untuk dipelajari (Hermawan;2017). Penggunaan komputer secara spesifik untuk mempermudah pekerjaan tertentu mungkin belum mereka kuasai. Namun demikian, kebiasaan berinteraksi dengan komputer akan membuat mereka lebih mudah berkembang. Oleh sebab itu, perangkat desa generasi "muda" layak mendapatkan hak mereka yaitu berhak mendapatkan akses informasi melalui sistem informasi desa yang dikembangkan oleh pemerintah daerah kabupaten/kota dalam bentuk pengembangan sumberdaya manusia. Bagi kelompok ini undang-undang desa merupakan penuntun bagi mereka untuk dapat terus berkembang.

Namun solusi kedua yakni pengembangan sumber daya manusia juga tidak kalah pentingnya, karena baik pegawai yang berusia diatas dan dibawah 40 tahun berhak mendapatkan kesempatan untuk mengembangkan diri untuk itu pemerintah bekerja sama dengan perguruan perguruan tinggi harus lebih menggiatkan kegiatan pemahaman komputer terhadap perangkat desa (Syafiul;2015) 


\section{KESIMPULAN}

- UU No 6 Tahun 2014 di dalam Mewujudkan Administrasi Desa Yang Efektif Dan Efisien berpegang pada pasal 86 terkait pengembangan aset SDM dan aset fisik yang pengelolaannya dipercayakan pada Perangkat Desa sebagaimana Diatur Dalam Pasal 48-53 UU Desa sesuai prosedur pengadaan barang/jasa yang bertujuan meningkatkan efisiensi dan efektifitas pelayanan desa supaya tercapai keadilan sosial bagi seluruh rakyat Indonesia.

- Hambatan yang timbul muncul terutama dari segi SDM dimana masih banyak warga Indonesia yang memiliki minat baca rendah dan pemahaman komputer yang rendah yang tentu berdampak kepada tenaga kerja yang menduduki jabatan perangkat desa.

- Solusi yang bisa diberikan untuk mengatasi hal ini ialah regenerasi perangkat desa dan pengembangan sumber daya manusia.

\section{DAFTAR PUSTAKA}

[1] Badan Kepegawaian Negara,(2017), Publikasi Statistik Indonesia 2007-2009.

[2] Hernawan Sulistyanto,(2017), Pakom Pelatihan Pengoperasian Komputer bagi Perangkat Desa di Kecamatan Gondangrejo Kabupaten Karanganyar, Warta. 2017;20(2):111-119 DOI 10.23917/warta.v20i2.4757

[3] Lawrence Friedman,(1994), American Law, W.W Norton \& Company, London.

[4] Lili Rasjidi \& Wyasa Putra.(1993). Hukum sebagaiSuatu Sistem, PT. Remaja Rosdakarya: Bandung

[5] Rony Hanitijo Soemitro,(1990), Metodologi Penelitian Hukum dan Jurimetri, Ghalia Indonesia, Jakarta.

[6] Syafiul Muzid, Noor Latifah, (2015), Pemanfaatan Sms Gateway Multi Direct Untuk Penyebaran Informasi Desa Melalui Sistem Layanan Informasi Desa, Simetris: Jurnal Teknik Mesin, Elektro dan Ilmu Komputer. 2015;6(2):415420 DOI 10.24176/simet.v6i2.480

[7] http://www.beritasatu.com/kesra/445506-kemdikbud-melekhuruf-tinggi-minat-baca-rendah.html

[8] Dhita Setiawan, Artikel,Alokasi Dana Desa Tahun Anggaran 2019 Bertambah Maksimal Rp 85 Triliun, Pikiran Rakyat, 11 Maret 2018

[9] http://www.pikiran-rakyat.com/nasional/2018/03/11/alokasidana-desa-tahun-anggaran-2019-bertambah-maksimal-rp-85triliun-421017

[10] https://tekno.kompas.com/read/2016/10/24/15064727/2016.p engguna.internet.di.indonesia.capai.132.juta.

[11] https://kominfo.go.id/index.php/content/detail/5890/Kemko minfo+Terus+Berdayakan+Masyarakat+Semakin+Melek+TI K/0/berita_satker 